the praises bestowed on the engine show that he was justified by the results. Mr. Bartholdi, in a report to the French Government, said enthusiastically that it belonged to the category of works of art, from its general beauty of effect, and its perfect balance to the eye; while Professor Redinger, of the Polytechnic School of Vienna, pronounced it "systematic in greatness, beautiful in form, and in every detail a masterpiece."

The Corliss collection contains his medals, and a copy of the Diploma of Honor he won at Vienna, in addition to the patents and correspondence. Much of the latter is concerned with the awarding of the Rumford Medals. It is largely between Corliss and James B. Francis of the Rumford Committee. The former seems to have been very particular about the wording of the description which was to be read when the medals were presented. However, a form was at length agreed upon, with but one rift in the lute, when Mr. Francis was moved in a moment of impatience to depart from the generally eulogistic tone of the letters to say:

"Your memo I have read with interest. Prof. Gray being a Botanist will no doubt prefer yours as the most flowery."

For the most part relations seem to have been most satisfactory. There is little in his later correspondence to give the reader a very clear idea of Corliss as a personality. Their diction is businesslike, and more or less formal, in spite of the informality of their appearance, owing to the writer's having crossed out several lines at a time in some places. Those written to him show contemporary opinion of his inventions, whose dicta have been borne out by time. For from 1876 , when his huge engine drove the machinery at the Centennial, to the coming of the steam turbine, the Corliss engine was the standard mill and factory prime-mover of this country.

\title{
Westward by Canal
}

"HERE and there in Ohio, Indiana and the Eastern States," says Alvin F. Harlow in his book, Old Towpaths, "the pedestrian ... may sometimes notice the faint indication of an embankment or a shallow depression, weed-grown but stretching away with such regularity of line as to rouse his belief that it may be an artificial work. ... If he will inquire in the neighborhood he may find some white-bearded ancient who remembers that these poor ruins are all that is left of what was once a great internal improvement, the pride of the locality and the State - a canal." 


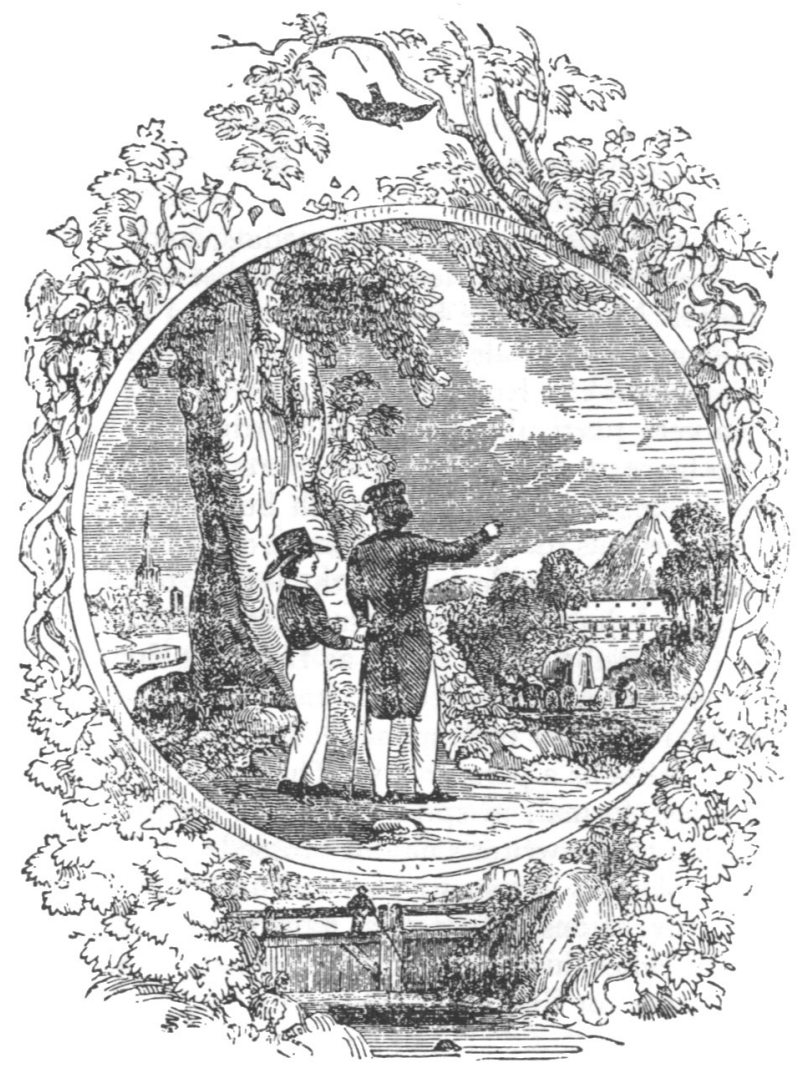

An Illustration from an Old Book on the

\section{Erie Canal for Children, by the} Author of the "Rollo Books"

This is one of a series of Marco Paul's Travels and Adoentures in the Pursuit of Knowledge. The picture shows a canal boat at the left and a Conestoga wagon at the right. 
William Dean Howells writes that canals in 1837 were a greater achievement than railroads were in 1897 . Before the railroad came, there was an elaborate system of them, built with characteristic American enthusiasm and enterprise, by men who were not professional engineers, many of whom had never seen a canal. The Erie gave New York her start toward becoming the American metropolis, and Pennsylvania had a system of state canals, supplemented by short railroads, which connected Philadelphia with Pittsburgh.

An expense account and diary kept during a trip over this Pennsylvania Main Line in 1835 gives an interesting picture of this form of transportation in its heyday. It seems to be a record of the expenditures and experiences of a Mrs. Adams and her three children, and also of a Mr. and Mrs. Lewis who accompanied them, from Boston to Cincinnati. The trip was made in short stages, by coach to Providence, thence by boat to New York, where passengers changed boats for Philadelphia, stopping in New York for breakfast. Philadelphia was connected with the first link of the canal system by a railroad running to Columbia on the Susquehanna. From there one travelled by canal boat to Hollidaysburg, at the foot of the Allegheny divide. The Portage Railroad carried passengers over the divide, by a series of inclined planes, the cars operated alternately by horse power and stationary engines. The last stage of the journey was again by canal, from Johnstown to Pittsburgh.

The "remarks" at the end of the expense account seem to have been written by Mr. Lewis. After some description of Philadelphia, he begins his account of the journey in the "carrs" which were drawn by horses to the foot of the first inclined plane, which they "ascended by means of machinery.... At the top of the hill wife and I stepped out of the Carrs and walked into the engine building and viewed the working of the machinery and were satisfied that it was very safe but little or no danger with passenger Carrs as they were not heavy enough to break the rope.

"After getting nicely warmed in the Machinery room," he continues, "got into the Carrs and were eased down the hill again very pleasantly. Although the weather was unpleasant and Stormy in the forenoon, the Carrs were quite leaky, the view of fine farms, orchards, and other Scenery passed the time off quite pleasantly."

At Lancaster they had at the "dining house, (we could ascertain no other name for it); very good beef and well cooked and good 
bread but poor pies \&c." The price of this meal does not appear, but dinner on the railroad is listed at $\$ I . \infty$ for Mrs. Adams and the three children.

On the boat, which was so late that the party had given up hope of its arrival that night and gone to bed, Mr. Lewis says that they "soon got snug into their berths and had a very good nights sleep." Either they chose a more favorable season than did Dickens on his visit to America, or they were better seasoned travellers. His first impression of the snug berths was that they were "three long tiers of hanging book shelves designed apparently for volumes of the small octavo size. Looking with greater attention at these contrivances," says he, "I descried on each shelf a sort of microscopic sheet and blanket; then I began dimly to comprehend that the passengers were the library, and that they were to be arranged edgewise on these shelves till morning."

Berths were sometimes assigned by precedence, and sometimes by lot.

Breakfast consisted of shad, beef steak, sausage, and first rate bread. With the whole charge for meals on the canal boat to Hollidaysburg given at $\$ 4.25$, this seems very good fare for the money. The fish was caught from the boat, as it proceeded at the pace of about four miles an hour. Mr. Lewis remarks that "it seemed to be a complete time of leisure on board the boat, some employed themselves in reading, some in conversation, and some in sleeping. I should say about equally divided.

"We came to a bend in the canal about 7 Oclock this morning," he says, "where the captain said that we might have walked across by travelling a distance of about $\frac{3}{4}$ of a mile and the Boat would have to go 5 Miles but it being about breakfast time we thought it best to stay by the boat. We stoped at this place and got some milk \&c."

He describes the trip over the Portage Railroad, with the mountains "very steep and high, presipices often hanging over us in frightful appearances." They were late in consequence of the Chief Engineer's ordering the suspension of the use of the engine on the Sabbath, as one day a week was needed for repairs, the railroad not yet having its full complement of engines.

On the second canal boat a ten year old boy created some excitement by falling overboard, and being promptly rescued by one of the hands. The child was one of six who, with their mother, had started for Detroit. Their father, who had "gone out to that coun- 
try to look out a situation, had agreed to meet his wife and children at Portsmouth on the Ohio. She not finding him there prefered proceeding on with her six children than to wait longer for him on expense."

Probably the Adamses or the Lewises themselves were also a part of the tide of emigration that swept westward over the canals at that period. The accounts for the two families present an amusing medley of items, some of which suggest permanence in the new country. Mr. Lewis seems to have bought two calves, a full blooded Durham bull, and a heifer, half Durham and half Ayrshire, for $\$ 40.00$. Other items are an umbrella, for a dollar; "cloth for N's. Pantaloons; Worcester's third book; Barnes' Notes on the Gospels; Bronze Snuffers; Hat Tree; 2 Bl. Covers \& a Chair; Book Shelves \& Rocking Chair; China tea set; pants at Newmans; and Subscribed for the Missionary Herald."

Cake and lemonade, and gingerbread and lemonade appear frequently among the travelling expenses. A map of Ohio is one entry, and "oranges and shaving," aggregating nineteen cents, is another.

The casual little record leaves the travellers keeping the Sabbath at Utica by attending the Presbyterian Meeting House. If the rest of their history is left in obscurity, we can at least be sure that they could face whatever difficulties were in store for them with a good conscience.

\section{The Mail Stage in Massachusetts}

THE thought of how short a time we have been modern is brought to mind by remembering that less than a century ago mail stages were running in Massachusetts. The Indian Tavern, Bromfield Street, was the starting point for lines to Newport, New Bedford and Bristol, and until 1840 they furnished the regular mode of conveying mail to those towns and intermediate points. The mail was still carried by private contractors, and the elements of chance and whim on the part of drivers still entered into its delivery, on time and in good order.

One of a bundle of old letters, written to Nathaniel Blake, stage owner, between I 824 and I 845 , attests this state of affairs. It is a communication from the Assistant Post Master General, in regard to the fact that the "Boston Mail, Route 2971, was in a very wet and injured condition on its arrival at Taunton on the 6th inst. This injury was sustained, it is said, in consequence of the careless- 